\title{
Black, pinto and white beans lower hepatic lipids in hamsters fed high fat diets by excretion of bile acids
}

\author{
Priscila L. S. Alves ${ }^{*} \mathbb{D}$, Jose De J Berrios, James Pan and Wallace H. Yokoyama
}

\begin{abstract}
Hypolipidemic and anti-obesity properties of extruded black, pinto and white beans were examined in male Syrian hamsters fed high fat diets for 3 weeks. The efficiency and effectiveness of extruder processing to eliminate heatlabile antinutrients were also determined. Hamsters fed a high fat diet containing 40\% extruded black beans gained the same amount of weight as animals on a low-fat chow diet (based on AIN-93G). Total plasma cholesterol of the hamsters fed bean flour- based diets tended to be lower, ranging between 298 and $356 \mathrm{mg} / \mathrm{dL}$, compared to 365 $\mathrm{mg} / \mathrm{dL}$ for the control group and total and free liver cholesterol was about 50 and $33 \%$ lower, respectively, in the livers (freeze-dried) of hamsters fed the black turtle bean (BB) and pinto bean (PB) diets. The nitrogen content of the feces from hamsters fed the PB and white bean (WB) diets were 2.6x higher than the control and the excretion of deoxycholic acid (DCA) and lithocholic acid (LCA) was higher in all legume fed hamsters The results show that extrusion efficiently and economically reduces anti-nutritive factors that inhibit the digestion and absorption of proteins and carbohydrates.
\end{abstract}

Keywords: Beans, Extrusion, Anti-obesity, Bile acid, Mice

\section{Introduction}

Diets high in plant foods have been associated with improved health (Petersen et al. 2017). Legumes, including dry beans are considered a low fat $(1-6 \%)$, high protein (20-25\%), and high dietary fiber $(15-30 \%)$ and have a low glycemic index (Asif et al. 2013; Mojica et al. 2015) that may reduce caloric intake when substituted for high fat foods (McCrory et al. 2010). In the U.S., a country impacted by obesity, the U.S. Dry Bean Council estimates consumption at $7.5 \mathrm{lb}$./yr in 2019 and it has remained constant at about $6-8 \mathrm{lb} . / \mathrm{yr}$ over the past 20 years (USDA ERS Oct 9, 2012). This is far below the recommended $1 / 2$ c-eq/week (67.6 lb./yr) recommended by a panel of nutrition experts (U.S. Department of Health and Human Services 2005). Whereas bean

\footnotetext{
* Correspondence: prilealsa@gmail.com

Agricultural Research Service, United States Department of Agriculture, Healthy Processed Foods Research, Western Regional Research Center, 800 Buchanan St., Albany, CA 94710, USA
}

consumption is low in the U.S., pulses, such as chickpeas (Cicer arietinum L.) and the common bean (Phaseolus vulgaris L.), are staple foods in many countries (Alajaji and El-Adawy 2006;Al-Numair et al. 2009; Xu and Chang 2008). In developing countries, the contribution of pulses to energy intake is second only to that of cereal grains (Juliano 1999; Siddiq and Uebersax 2012). Pinto beans are the most consumed beans in the U.S., accounting for about $47 \%$ of total dry bean consumption.

Uncooked or improperly cooked pulses contain significant levels of antinutritive factors including trypsin and chymotrypsin inhibitors, oxalate, lectins, raffinose family oligosaccharides, saponins, phytate, and tannin (De Almeida Costa et al. 2006; El-Adawy 2002; Sandberg 2002; Wang et al. 2010). Most of the antinutrients that affect protein digestibility are heat sensitive, thus cooking alone improves protein digestibility and safety in pulse-based diets (Nergiz and Gokgoz 2007;

(c) The Author(s). 2020 Open Access This article is licensed under a Creative Commons Attribution 4.0 International License, which permits use, sharing, adaptation, distribution and reproduction in any medium or format, as long as you give appropriate credit to the original author(s) and the source, provide a link to the Creative Commons licence, and indicate if changes were made. The images or other third party material in this article are included in the article's Creative Commons licence, unless indicated otherwise in a credit line to the material. If material is not included in the article's Creative Commons licence and your intended use is not permitted by statutory regulation or exceeds the permitted use, you will need to obtain permission directly from the copyright holder. To view a copy of this licence, visit http://creativecommons.org/licenses/by/4.0/. 
Tharanathan and Mahadevamma 2003). Shimelis and Rakshit (2007) studied the effect of processing on antinutrients and in-vitro protein digestibility of kidney beans. The combination of pre-soaking and cooking grains at $97^{\circ} \mathrm{C}$ for $35 \mathrm{~min}$ significantly reduced trypsin inhibitors, lectins and saponins to undetectable levels.

Extrusion cooking is highly effective in reducing antinutritive properties of legumes. Alonso et al. (2000) compared the effects of extrusion cooking and conventional processing methods on protein content and reduction of antinutritional level of phytic acid, trypsin, chymotrypsin, $\alpha$-amylase inhibitors and hemagglutinating activity in Vicia faba and $P$ vulgaris seeds.

Natural phytochemicals present in these plant foods can have synergistic effects and attenuate hyperlipidemia through regulating some genes involved in lipid metabolism (Aune et al. 2016; Chávez-Santoscoy et al. 2013). Consumption of $P$ vulgaris extract alleviated dietinduced obesity, insulin resistance and hepatic steatosis in obese C57BL/6 mice fed high-fat diets (HFDs) (Song et al. 2016). Particularly, common beans have been considered as hypolipidemic agents due to their cholesterollowering properties (Han et al. 2003; Han et al. 2004), food intake reduction (Fantini et al. 2009; Nilsson et al. 2013; Spadafranca et al. 2013) and inhibition of intestinal lipid absorption (Chávez-Santoscoy et al. 2013; Han et al. 2003; Han et al. 2005).

The objectives of this study were to show that extrusion processed beans are safe and nutritious, and also examines the hypolipidemic and anti-obesity properties of black, pinto and white beans in male Syrian hamsters fed high fat diets.

\section{Materials and methods Materials}

The black turtle bean (BB), pinto bean (PB) and Great Northern white bean (WB) varieties of Phaseolus vulgaris were purchased Guisto's Vita-Grain, South San Francisco, $\mathrm{CA}$. The beans were milled into fine flour using a pinmill, model 160z (Hosakawa Micron, Koln, Germany) to obtain flour with uniform particle size $(0.05 \mathrm{~mm})$.

\section{Extrusion processing}

A Clextral EVOL HT32-H twin-screw extruder (Clextral, Inc., Tampa, FL, USA) with co-rotating, intermeshing screws, six barrel sections (128 $\mathrm{mm}$ each), screw diameter $32 \mathrm{~mm}, \mathrm{~L} / \mathrm{D}$ ratio 24 and $25 \mathrm{~kg}$ feed/h was used. The last barrel section and die temperature was maintained at $140 \pm 1 \mathrm{C}$. Screws were driven by a $74.8 \mathrm{~kW}$ variable speed drive, Model ACS600 (ABB Automation Inc., New Berlin, WI, USA). The screw speed was maintained constant at $500 \mathrm{rpm}$ resulting in an estimated total residence time of $90-120 \mathrm{~s}$. A combination of feeding, transporting, compression, and kneading elements was used to provide a moderate shear screw configuration. The bean flours were metered into the feed port by a twin-screw, loss-in-weight gravimetric feeder, Model LWFD5-20 (K-Tron Corp., Pitman, NJ, USA) at a rate of $25 \mathrm{~kg} / \mathrm{h}$ (wwb). Water was supplied to the extruder by a triplex variable stroke piston pump with 12 mm plungers, Type VE-P33 (Bran and Luebbe, Wheeling, IL, USA) to provide a final moisture content of $21 \%$. The black, pinto and white beans were extruded through two circular dies each with $3.5 \mathrm{~mm}$ diameter openings. Pressure at the die was determined using a pressure transducer, Type PT412-5M (Dynisco Instruments, Sharon, MA, USA). A PLC+ Industrial computer (AllenBradley, Milwaukee, WI, USA) using Intouch software (FITSYS PLUS, ver. 1.23) to collect extruder parameter data at $1 \mathrm{~s}$ intervals for a total of $5 \mathrm{~min}$. Data were collected approximately $10 \mathrm{~min}$ after the operation conditions of torque and pressure were at steady state. A beltdrive cyclone lab sample mill (Udy Corporation, Fort Collins, CO, USA) fitted with a $0.5 \mathrm{~mm}$ screen, was used to mill the extrudates to uniform powders and the extrudates were stored in air-tight high density polyethylene food grade containers at room temperature until used in the diets.

\section{Animals and diets}

Forty male Syrian hamsters (approximately 51-60 g) were purchased from Charles River Laboratories (Kingston, NY, USA). The hamsters were housed individually in an environmentally controlled rooms, at a temperature between 20 and $22{ }^{\circ} \mathrm{C}$, relative humidity at $60 \%$, light-dark cycle of $12 \mathrm{~h}$ dark/light. Hamsters were fed commercial chow (Purina Rodent, St. Louis, MO) with free access to water for 1 week prior to the initiation of the experimental diets to acclimate to their housing. After one-week acclimatization period, the hamsters were weighed, and ten animals were randomly assigned to each diet treatment after a weight rank sort. The compositions of the diets are shown in Table 1. Diet (A) control, Diet (B) contained $399 \mathrm{~g}$ of extruded black beans, Diet (C) contained $410 \mathrm{~g}$ of extruded pinto beans and Diet (D) contained $402 \mathrm{~g}$ of extruded white beans. The bean and control diets were formulated to provide $21 \%$ protein, $10 \%$ dietary fiber, $21 \%$ fat, carbohydrates, and hamster vitamin and mineral mix (Dyets, Bethlehem, PA). Hamsters were fed twice each week and weighed once each week for a period of 3 weeks. The animal study protocol was approved by the Institutional Animal Care and Use Committee of Western Regional Research Center, USDA, Albany, CA, USA, (Protocol \#14-1) and all experiments followed the Guide for the Care and Use of Laboratory Animals (8th Edition) of National Research Council. 
Table 1 Diet Composition (Grams)

\begin{tabular}{lllll}
\hline Ingredient & Control & BB & PB & WB \\
\hline Butter & 80 & 80 & 80 & 80 \\
Corn Oil & 110 & 100 & 105 & 105 \\
Fish Oil & 20 & 20 & 20 & 20 \\
Cholesterol & 1 & 1 & 1 & 1 \\
Cellulose & 105 & 45 & 0 & 0 \\
Casein & 230 & 118 & 126 & 127 \\
Legume & 0 & 399 & 410 & 402 \\
Corn Starch & 474 & 266 & 293 & 304 \\
Methionine & 6 & 6 & 6 & 6 \\
Choline Bitartrate & 6 & 6 & 6 & 6 \\
Vitamin Mix & 10 & 10 & 10 & 10 \\
Mineral Mix & 35 & 35 & 35 & 35 \\
Total weight & 1000 & 1000 & 1000 & 1000 \\
\hline
\end{tabular}

\section{Nutritional composition analysis}

Ash was determined according to the AACC method 0801 (AACC, American Association of Cereal Chemists 2000). Fat was determined by weight difference after extraction with hexane/isopropanol $(3,1 \mathrm{v} / \mathrm{v}$,$) at 100^{\circ} \mathrm{C}$ and $2000 \mathrm{psi}$ in an accelerated solvent extractor (ASE), model 200 (Dionex Corp., Sunnyvale, CA, USA). Proteins content was determined indirectly through quantification of total nitrogen in $20 \mathrm{mg}$ of sample. Nitrogen concentration was determined using a TruSpec $\mathrm{N}$ nitrogen analyzer (Leco Corporation, St. Joseph, MI, USA) and protein was calculated using a conversion factor of 6.25 .

\section{Plasma and tissue collection}

After 3 weeks of feeding, hamsters were fed deprived for $12 \mathrm{~h}$ and anesthetized with isoflurane (Phoenix Pharmaceutical, St. Joseph, MO, USA). Blood samples were collected by cardiac puncture with syringes previously rinsed with EDTA solution (15\%, w/v). Following collection, plasma samples were transferred to $5 \mathrm{~mL}$ polypropylene tubes and centrifuged at $2000 \mathrm{x} \mathrm{g}, 15 \mathrm{~min}$ at $4{ }^{\circ} \mathrm{C}$ for plasma separation, plasma samples were stored in $-80^{\circ} \mathrm{C}$ for further analysis.

\section{Plasma lipoprotein analysis}

Plasma lipoprotein cholesterol was determined according to our previous method (German et al. 1996). Plasma triglyceride (TG) was determined by enzyme colorimetric assay kit (Sekisui 100 Diagnostics PEI Inc., PE, Canada) according to the manufacturer's instruction, and the 101 absorbance was measured at $505 \mathrm{~nm}$ (Nanodrop 2000C spectrophotometer, Thermo Scientific, 102 USA). Liver lipids were determined as described before (Kim et al. 2014).

\section{Sterols and bile acids analysis}

Bile acids in feces were determined as in Hagio et al. (2009). Sterols and bile acids were separated and quantitated by HPLC and evaporative light scattering detection. A reversed phased HPLC system from Agilent Tech, model 1100 (Palo Alto, CA, USA) equipped with a Luna C18 column $(5 \mu \mathrm{m}, 250 \times 4.6 \mathrm{~mm}$, Phenomenex, Torrance, CA, USA) were used. Separation was performed using a gradient of two mobile phases: (A) methanol/acetonitrile/water $(53,23: 24, \mathrm{v} / \mathrm{v} / \mathrm{v})$ and (B) isopropyl alcohol (100\%). Both phases were made up to 30 $\mathrm{mM} \mathrm{NH} \mathrm{N}_{4}$ Ac. Solvent A was acidified by the addition of $24 \mathrm{~mL}$ of glacial acetic acid in $1 \mathrm{~L}$. A linear gradient from A to $B$ at a flow rate of $0.5 \mathrm{~mL} / \mathrm{min}$ was performed as follows: time of $0-30 \mathrm{~min}, 8-36 \% \mathrm{~B}$; time of $30-40 \mathrm{~min}$, $36-50 \% \mathrm{~B}$; time of $40-100 \mathrm{~min}, 50-56 \% \mathrm{~B}$; time of $100-$ $105 \mathrm{~min}, 56-70 \% \mathrm{~B}$; time of $105-145 \mathrm{~min}, 70-88 \% \mathrm{~B}$; and time of $145-170 \mathrm{~min}, 88-95.5 \% \mathrm{~B}$. In all experiments, the columns were re-equilibrated between injections with the equivalent of $10 \mathrm{~mL}$ of the initial mobile phase. The LC effluent was monitored by the Varian evaporative light scattering detector (ELSD), model PLELS 1000 (Varian, Inc., Amherst, MA, USA) with a nitrogen gas flow of $1.3 \mathrm{~L} / \mathrm{min}$ and desolvation and evaporation temperatures set to 100 and $120^{\circ} \mathrm{C}$, respectively.

\section{Quantitation of bile acids and sterols by LC-ELSD}

Peaks observed by ELSD were identified using APCIMS by determining the mass to charge ratio $(\mathrm{m} / \mathrm{z})$ in the positive mode. The recovery of bile acids and sterols in feces was determined by a comparison with the recovery of internal standards: hyodeoxycholic acid and 5Rcholestane. Once bile acids and sterols in feces samples were identified by MS, the calibration curves of compounds in hamster feces were generated according to peak areas acquired by ELSD and used to quantitate these compounds in feces samples.

\section{Fecal total lipid analysis}

Feces were collected during the final 3 days of the study, and then freeze dried. The freeze dried lipids were extracted with hexane/isopropanol $(3: 1, \mathrm{v} / \mathrm{v})$ at $100^{\circ} \mathrm{C}$ and 2000 psi by a Dionex ASE, model 200 (Dionex Corp., Sunnyvale, CA, USA). Dry feces were analyzed for nitrogen content by combustion analysis using Leco TrueSpec N analyser (Leco Corp., St. Joseph, MI, USA).

\section{Statistical analysis}

The significance of differences between individual groups was analyzed by two-tailed $\mathrm{t}$ test, in triplicate. Significance level was set at $p<0.05$. 


\section{Results and discussion}

\section{Nutritional composition analysis and body weight}

The proximate compositions of the $\mathrm{BB}, \mathrm{PB}$ and $\mathrm{WB}$ were: $27.1,24.6$ and $25.1 \%$ protein; $16.0,27.4$ and $28.2 \%$ total dietary fiber; 4.4, 4.1 and $4.3 \%$ ash; 9.9, 11.0 and $11.7 \%$ moisture; and 39.9, 31.7, and 29.4\% carbohydrate by difference, respectively. These results are similar to (Wang et al. 2010) who found no significant difference in protein, dietary fiber or ash content between these legumes. The legume diets contained about $40 \%$ legume flour and $12-13 \%$ protein (Table 1). The total dietary fiber (TDF) contents of the black, pinto and white beans were 16, 27 and 28\%, respectively. Microcrystalline cellulose (MCC) was used to supplement dietary fiber (DF) content of the BB diet because the black bean flour was $58 \%$ lower in DF than the pinto and white bean flours. $\mathrm{MCC}$ is insoluble, non-viscous, only slightly fermentable and considered to have little or no effect on plasma cholesterol.

Uncooked legumes are known to contain anti-nutritive components such as phytic acid, lectins, condensed tannins, and inhibitors of trypsin, chymotrypsin, and $\alpha-$ amylase. The adverse effect of excessive cooking on protein denaturation is also a crucial factor to be considered during feed processing. Appropriate cooking is necessary to eliminate these anti-nutritive components. Extrusion cooking at $150{ }^{\circ} \mathrm{C}$ has been shown to eliminate the protease and $\alpha$-amylase inhibitors in kidney beans (Marzo et al. 2002).

In this study weight gains of the hamsters fed the $\mathrm{BB}$, $\mathrm{PB}$ and WB-based diets and the body weight were significantly higher compared to the control-based diet. The high level and higher quality of combined casein and legume protein suggests that protein quality was not a limiting factor. The greater weight gain of hamsters on the WB diet was in spite of the increased feed weight needed to increase body weight, $4.2 \mathrm{~g}$ feed $/ 1 \mathrm{~g}$ body weight gain and higher fecal lipid excretion (Table 2). These weight gain results demonstrate the efficacy of extrusion to eliminate anti-nutritive factors that might decrease protein, fat, or carbohydrate digestion and absorption. The inactivation of trypsin inhibitors and other antinutrients activity by extrusion processing has previously been reported by Morales et al. 2015. Hamsters fed the WB diet excreted almost three times more lipid than the control group and twice as much as the hamsters fed the other bean-based diets. These results may be due to the known effects of dietary fiber to increase lipid excretion (Hong et al. 2007).

Casein is the protein source for AIN-93 diets, but casein is low in methionine and therefore AIN-93 diets are supplemented with methionine. All of the legume-based diets contained about $12 \%$ casein so that the overall protein quality of the diets was high. The three legumes contained $0.32 \%$ methionine and $0.23 \%$ cystine. The minimal methionine and cystine recommended for rats in AIN-93G (growth phase) diets are 0.46 and $0.37 \%$, respectively (Reeves et al. 1993). Casein typically contains about 4\% combined methionine and cystine (Roman and Sgarbieri 2005) so that our diets contained about $0.48 \%$ of these sulfur amino acids derived from casein, and the legumes contribute about $0.2 \%$. All diets were also supplemented with $0.6 \%$ methionine so that combined with the casein and legume sources they meet the minimum recommended requirements for AIN-93G diets.

The hamsters on all bean-based diets had higher intake of feed compared to the control, but none were significantly different from the control. The white bean diet group had $17 \%$ higher feed intake than the control group. Weight gain was significantly greater in hamsters fed the black bean and white bean diets. The weight gain by animals on the bean-based diets demonstrated that the anti-nutrient factors present in raw beans were effectively eliminated by the extrusion processing conditions employed. The influence of extrusion cooking on the protein content, amino acid profile, and concentration of antinutritive compounds (phytic acid, condensed tannins, polyphenols, trypsin, chymotrypsin, alphaamylase inhibitors, and hemagglutinating activity) in kidney bean seeds (Phaseolus vulgaris L. var. Pinto) was investigated by Marzo et al. 2002. Pretreatment of the beans by extrusion cooking improved food intake and

Table 2 Body and organ weights, feed intake and fecal lipid excretion of Hamsters fed extruded black, Pinto and White beans for 3 weeks

\begin{tabular}{lllll}
\hline & Control & Black bean & Pinto bean & White bean \\
\hline Final Body Weight (g) & $97.1 \pm 2.0$ & $102.6 \pm 2.0$ & $101.5 \pm 1.5$ & $103.6 \pm 2.3$ \\
Body weight Gain (g) & $39.1 \pm 1.9$ & $45.6 \pm 1.5$ & $44.1 \pm 1.6$ & $45.4 \pm 2.6$ \\
Liver weight (g) & $5.93 \pm 0.26$ & $5.93 \pm 0.18$ & $5.85 \pm 0.20$ & $5.97 \pm 0.27$ \\
Feed Intake/Weight Gain & $3.6 \pm 0.18$ & $3.3 \pm 0.15$ & $3.5 \pm 0.16$ & $4.2 \pm 0.46$ \\
Daily Dry Fecal Excretion (g) & $0.87 \pm 0.03$ & $0.83 \pm 0.04$ & $0.66 \pm 0.03$ & $0.58 \pm 0.04$ \\
Fecal N Excretion & $2.40 \pm 0.11$ & $3.80 \pm 0.11$ & $6.45 \pm 0.16$ & $6.18 \pm 0.18$ \\
\%Fecal Fat & $1.7 \pm 0.1$ & $2.2 \pm 0.2$ & $2.8 \pm 0.4$ & $4.9 \pm 0.6$ \\
\hline
\end{tabular}

All data reported in this table are in grams 
utilization by the rats and they weight gained (Marzo et al. 2002).

The daily dry weight of feces of the hamsters fed the $\mathrm{PB}$ and WB diets was lower than the Control or BB diets (Table 2) which suggests that pinto and white beans have a higher fermentable dietary fiber content than the control. Because the $\mathrm{BB}$ diet contains about half of the total dietary fiber of the $\mathrm{PB}$ and WB diets, the $\mathrm{BB}$ diet was supplemented with non-fermentable MCC. Phaseolus vulgaris contains fermentable fibers such as amorphous cellulose, hemicellulose, and pectin. Compositional analysis of some common legumes show that the hemicellulose content is typically $50-100 \%$ greater than cellulose content (Perez-Hidalgo et al. 1997). Soluble fibers are believed to be a major factor in the decrease in serum cholesterol in humans consuming legumes.

\section{Plasma lipoprotein profile}

The effects of feeding extruded black bean, pinto bean and white bean on total plasma cholesterol, plasma VLDL, plasma LDL and plasma HDL were analyzed after 3weeks. Total plasma cholesterol of the hamsters fed bean flour- based diets tended to be lower, ranging between 298 and $356 \mathrm{mg} / \mathrm{dL}$, compared to $365 \mathrm{mg} / \mathrm{dL}$ for the control group (Table 3). However, only total plasma cholesterol of the BB diet group approached significance $(p<0.05)$ and had the lowest values compared to the other bean diets. All lipoprotein fractions contributed to lowering of total plasma cholesterol of the BB diet (Fig. 1). Hamsters fed with BB diet had significantly $(p<0.05)$ lower VLDL and LDL concentration when compared to the control, PB and WB diets. Plasma HDL of hamsters on the bean flour-based diets were 19-24\% lower than the control diet fed animals (Fig. 1a). Hamsters fed with WB diet had lowest plasma HDL concentration and the highest plasma total cholesterol content when compared with all other bean diets. Additionally, contrary to the results observed for the other bean diets, hamsters fed WB diet had the highest plasma VLDL $(43.8 \mathrm{mg} / \mathrm{dL})$ and LDL $(217.7 \mathrm{mg} / \mathrm{dL})$.

The effect of the bean diets on lower plasma cholesterol was more pronounced in the liver (Table 3). Total and free liver cholesterol was about 50 and 33\% lower, respectively, in the livers (freeze-dried) of hamsters fed the $\mathrm{BB}$ and $\mathrm{PB}$ diets (Fig. 1b). Legume protein and fiber are known to reduce plasma cholesterol (Aziz et al. 2008).
The hypocholesterolemic properties of soy proteins have been studied extensively. Their bioactivity may be due to undigested hydrophobic peptides that displace cholesterol from micelles or bind to bile acids (Gatchalian-Yee et al. 1997). There were no differences in triacylglycerol (TAG) levels in the liver between any treatment.

The lower plasma LDL and VLDL of the hafmsters fed the black bean diet may be due to increased excretion of sterols. Both animal and plant sources of dietary cholesterol, and sitosterol and campesterol were higher in the feces of hamsters fed the black bean diet (Fig. 2a). Sterols are metabolized in the liver to bile acids and the level of cholesterol is maintained by excretion of bile acids. The major bile acids excreted by hamsters are typically deoxycholic acid (DCA) and lithocholic acid (LCA) (Daggy 1997). The excretion of DCA and LCA was higher in all legume fed hamsters (Fig. 2b). Hamsters on the black bean diet tended to have higher bile acid excretion. Additionally, working with inclusion of limited amounts of extruded legumes plus cereal mixes in normocaloric or obesogenic diets for rats, Rubio et al (2020) found a lowering $(p<0.05)$ excretion of cholic, chenodeoxycholic and ursodeoxycholic acids and deoxycholic acid and total bile acids higher $(p<0.01)$ for rats fed extruded mixes compared with controls.

This would be also in line with the increased excreted bile acids here reported (Fig. 2b), since increased bile acid excretion has also been claimed as a mechanism to explain the cholesterol lowering effect of legume protein-based diets through removal of blood cholesterol via the LDL receptor or bile acids binding within the intestine (Ngoh et al. 2017). Finally, bile acid metabolism is known to be modulated by gut microbiota, affecting the biotransformation, reabsorption, and excretion of bile acids by catalysing a range of biochemical reactions (Wahlström et al. 2016). Nakatani et al. (2018) have recently found an elevated cecal and fecal bile acid pool in mice that had consumed mung bean protein.

\section{Fecal total lipid analysis}

The nitrogen content of the feces from hamsters fed the $\mathrm{PB}$ and WB diets were 2.6x higher than the control and would amount to about $37 \%$ protein (Nx6.25). This is supported by research that the average protein digestibility of extruded beans compared to casein was 66\% (Nosworthy et al. 2018). Legume proteins may be less digestible and may also bind to dietary fiber and decrease

Table 3 Plasma and Liver Cholesterol and Triglycerides

\begin{tabular}{lllll}
\hline & Control & Black Bean & Pinto Bean & White Bean \\
\hline Total Liver Lipids, \% dry liver wt & $19.7 \pm 0.19$ & $13.3 \pm 0.1$ & $13.1 \pm 0.23$ & $15.1 \pm 0.15$ \\
Liver Free Cholesterol, mg/g & $24.7 \pm 0.36$ & $16.5 \pm 0.42$ & $17.4 \pm 0.38$ & $21.1 \pm 0.19$ \\
Liver TAG, mg/g dry weight & $25.7 \pm 0.26$ & $22.5 \pm 0.2$ & $18.0 \pm 0.16$ & $24.4 \pm 0.25$ \\
\hline
\end{tabular}



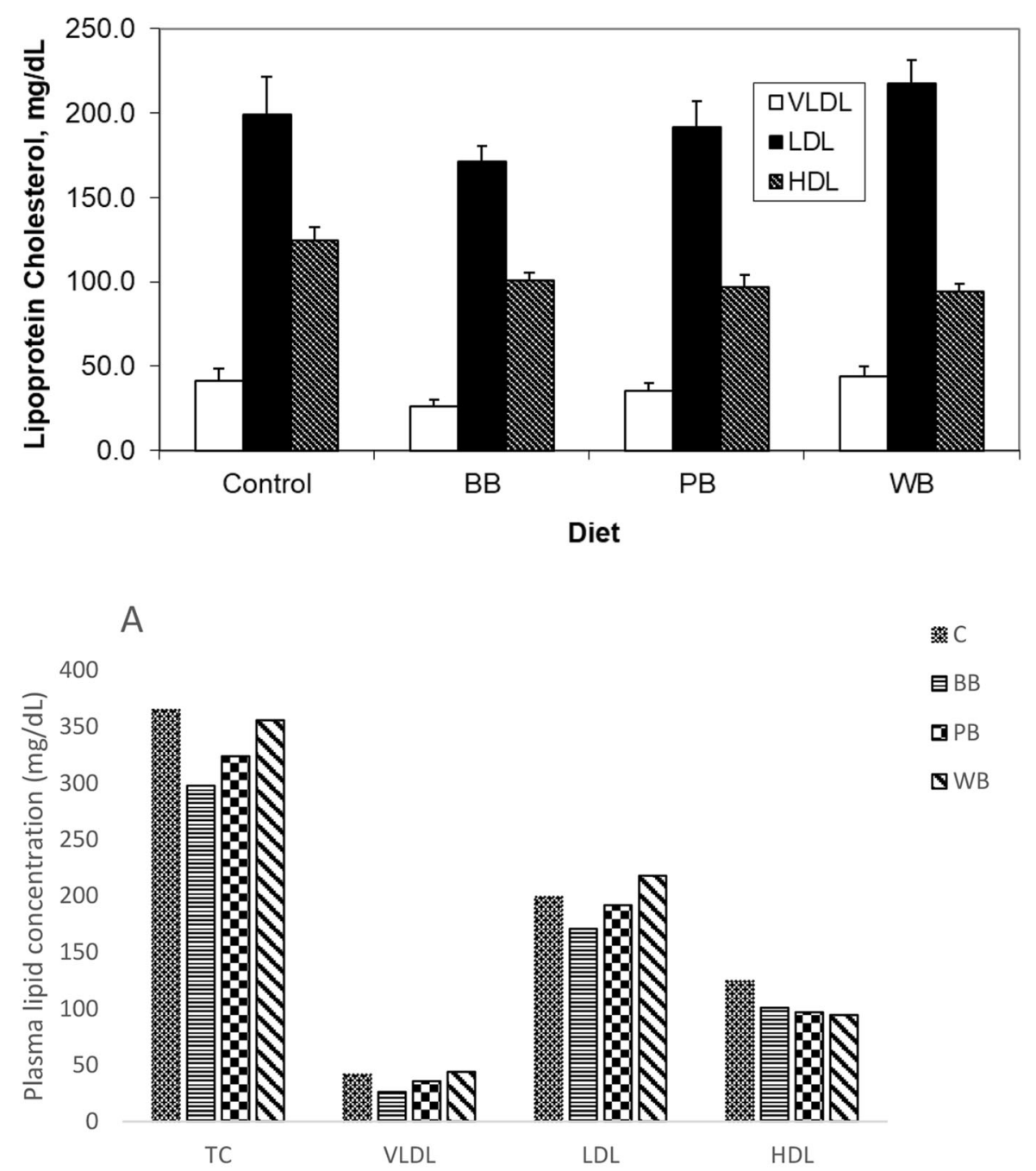

榇 $\mathrm{C}$
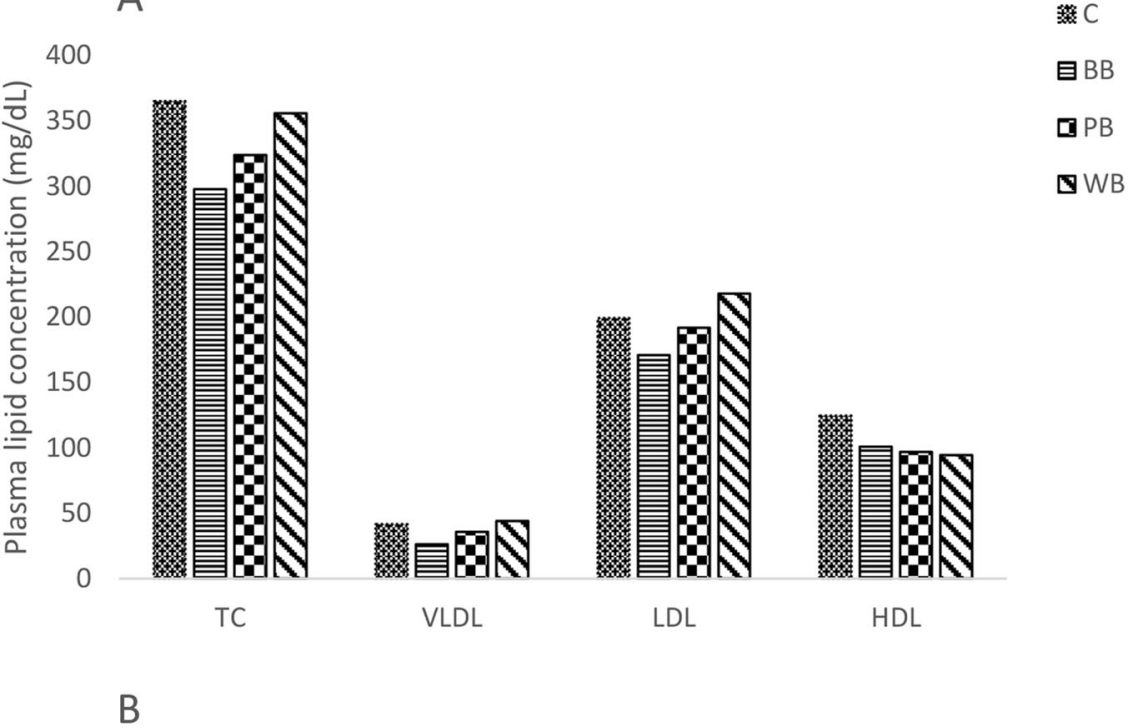

B

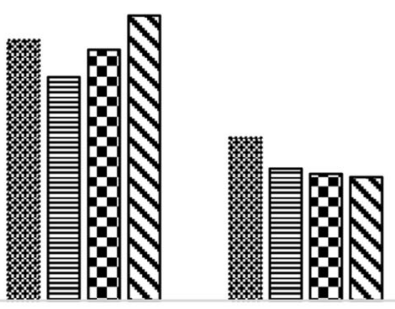

LDL HDL

$\mathbf{\nabla W B}$
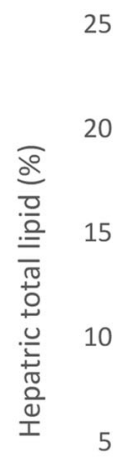

0
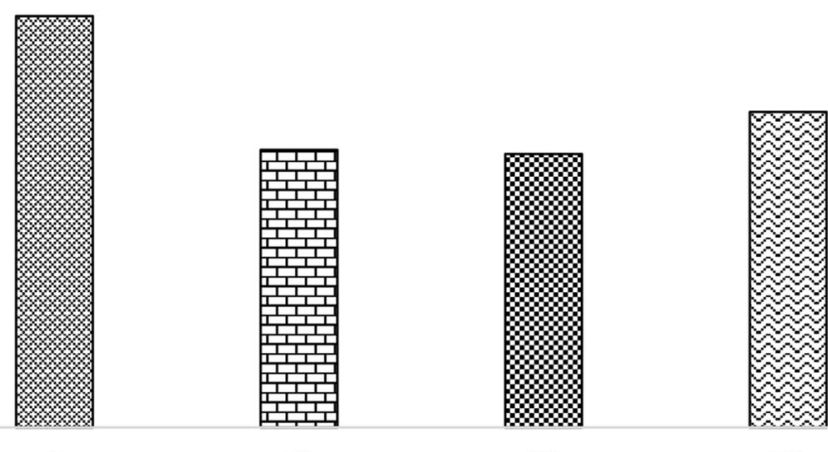

$\mathrm{BB}$

Diet

PB

Fig. 1 (See legend on next page.) 
(See figure on previous page.)

Fig. 1 Plasma lipoprotein profile of hamsters fed extruded black, pinto and white beans at 3 weeks. a Plasma lipid concentration in mice fed with high fat diet (C), high fat diet containing black bean (BB), high fat diet containing pinto bean (PB) and high fat diet containing white bean (WB) for 3 weeks. TC: total cholesterol; VLDL: very low-density lipoprotein; LDL: low density lipoprotein; HDL: high density lipoprotein. b Hepatic total lipid content in mice fed with high fat diet (C), high fat diet containing black bean (BB), high fat diet containing pinto bean (PB) and high fat diet containing white bean (WB) for 3 weeks

their bioavailability. In vitro analysis of protease digested, cooked black beans and cowpeas indicate that $18 \%$ of the proteins after enzymatic hydrolysis are bound preferentially to the cellulosic fraction and $3 \%$ to the lignin fraction (Hughes et al. 1996). The lignin fraction of the seed coat of navy beans was reported to be $1.4-1.9 \%$ compared to $58.7-65.0 \%$ of cellulose content (Srisuma et al. 1991). These reports suggest that the nonfermentable cellulose content of legume flours is the most excreted fiber and most likely to interact with nondigested protein. In this study, in contrast to the in vitro results, we find that black beans had higher fecal excretion with assumed higher fiber content but had decreased protein content compared to pinto or white

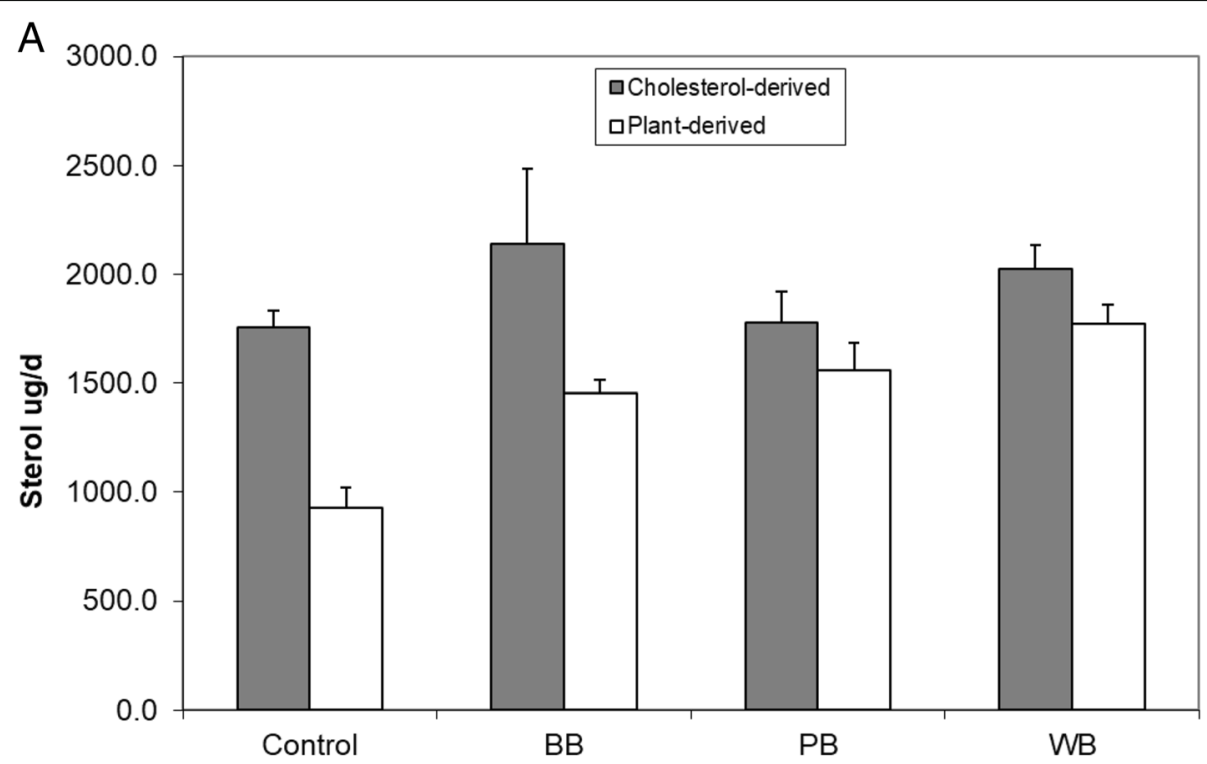

B

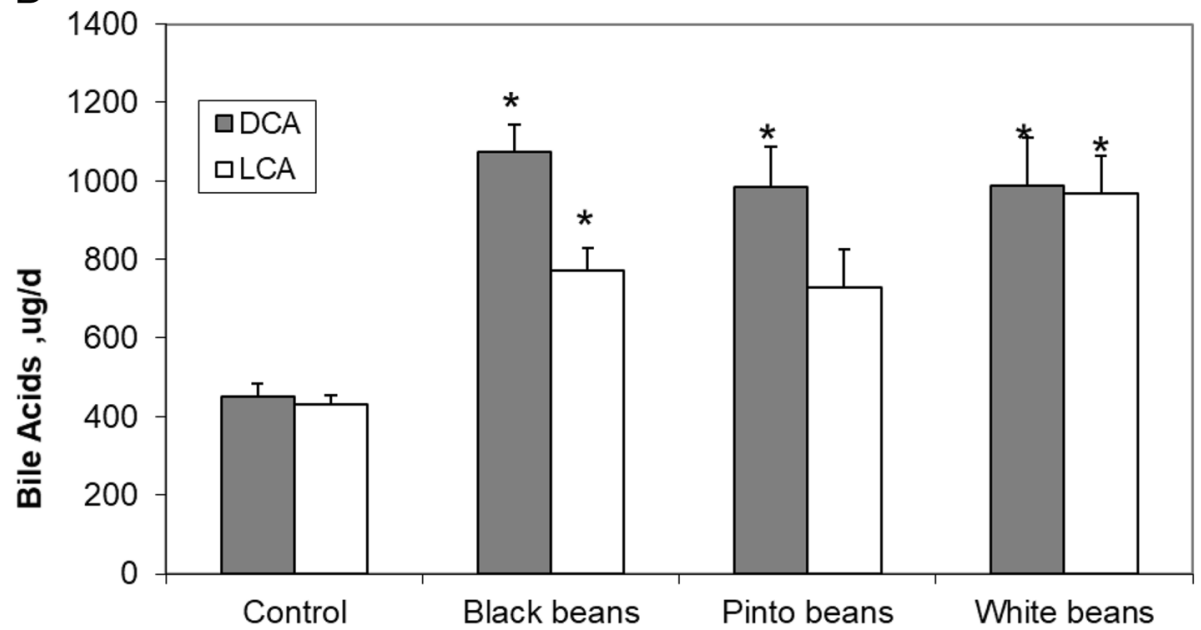

Fig. 2 a Fecal sterols in hamsters fed the high fat diet supplemented with cholesterol, butter and corn oil as sources of sterols. Animal derived sterol are derived from cholesterol and cholesterol in butter, and vegetable sterols and stanols are mainly from sitosterol and campesterol from corn oil. b Major fecal bile acids excretion from hamsters fed control and legume supplemented diets 
beans. These results may suggest that the cellulose of legumes is more active than the microcrystalline form used in the control and BB diets. A meta-analysis of eleven human studies places fiber as the most important contributor to cholesterol lowering in humans followed by legume protein.

Despite the lower body weight of the control group compared to the legume groups, we found that fecal lipid excretion was lower and would not have contributed to the lower weight gain (Table 2). Pinto and white beans fecal lipid content were significantly higher compared to the control.

\section{Conclusion}

The hamsters fed a diet containing $40 \%$ black beans extruded gained the same amount of weight as animals on a good rodent diet based on AIN-93G recommendations. Thus, extrusion efficiently and practically reduces anti-nutritive factors that inhibit the digestion and absorption of proteins and carbohydrates. Legume feeding resulted in lower fecal dry weight suggesting that legume dietary fibers are fermentable and may contribute to colonic health. Higher protein excretion and high fiber content may have contributed to reduced liver cholesterol and increased bile acid and cholesterol excretion by legume fed animals. Plasma HDL cholesterol reduced by all beans and the plasma VLDL was lowered by black beans, while liver fat was lowered by all beans.

\section{Abbreviations}

BB: Black turtle bean; PB: Pinto bean; WB: White bean; DCA: Deoxycholic acid; LCA: Lithocholic acid; HFDs: High-fat diets; TDF: Total dietary fiber; MCC: Microcrystalline cellulose; DF: Dietary fiber; VLDL: Very-low-density lipoprotein; HDL: High-density lipoprotein; LDL: Low-density lipoprotein; TAG: Triacylglycerol; TG: Triglyceride; ELSD: Evaporative light scattering detector; LC: Liquid chromatography; HPLC: High-performance liquid chromatography

\section{Acknowledgements}

Authors would like to acknowledge Dr. Yun-Jeong Hong for her help with the sterols and bile acids analysis.

\section{Authors' contributions}

PLSA designed experiments, collected and analyzed data, and prepared the draft of the manuscript. WY conceptualized the study, designed experiments, supervised the study, read and edited the manuscript. JB collected data, read and edited the manuscript. JP collected data, read and edited the manuscript. All authors read and approved the manuscript.

\section{Funding}

This research was supported by the United States Department of Agriculture.

\section{Availability of data and materials}

All data supporting this study are included in this manuscript. Further details. are available upon request from the corresponding author.

\section{Competing interests}

Authors declare that they have no competing interests.
Received: 3 July 2020 Accepted: 5 October 2020

Published online: 30 October 2020

\section{References}

AACC, American Association of Cereal Chemists (2000). Approved methods of the AACC. 10th methods. St. Paul: AACC.

Alajaji, S. A., \& El-Adawy, T. A. (2006). Nutritional composition of chickpea (Cicerarietinum L.) as affected by microwave cooking and other traditional cooking methods. Journal of Food Composition and Analysis, 19, 806-812.

Al-Numair, K. S., Ahmed, S. E. B., Al-Assaf, A. H., \& Alamri, M. S. (2009). Hydrochloric acid extractable minerals and phytate and polyphenols contents of sprouted faba and white bean cultivars. Food Chemistry, 113, 997-1002.

Alonso, R., Aguirre, A., \& Marzo, F. (2000). Effect of extrusion and traditional processing methods on antinutrients and in vitro digestibility of protein and starch in faba and kidney beans. Food Chemistry, 68, 159-165.

Asif, M., Rooney, L. W., Ali, R., \& Riaz, M. N. (2013). Application and opportunities of pulses in food system: A review. Critical Reviews in Food Science and Nutrition, 53, 1168-1179.

Aune, D., Keum, N., Giovannucci, E., Fadnes, L. T., Boffetta, P., \& Greenwood, D. C. (2016). Whole grain consumption and risk of cardiovascular disease, cancer, and all cause and cause specific mortality: Systematic review and doseresponse meta-analysis of prospective studies. BMJ, 353, i2716. https://doi. org/10.1136/bmj.i2716.

Aziz, A., Xiao, C. W., Cockell, K. A., Gilani, G. S., Cruz-Hernandez, C., \& Ratnayake, W. N. (2008). Impact of dietary protein on lipid metabolism in hamsters is source-dependent and associated with changes in hepatic gene expression. British Journal of Nutrition, 100, 503-511.

Chávez-Santoscoy, R. A., Gutiérrez-Uribe, J. A., \& Serna-Saldivar, S. O. (2013). Effect of flavonoids and saponins extracted from black bean (Phaseolus vulgaris L.) seed coats as cholesterol micelle disruptors. Plant Foods for Human Nutrition, $68,416-423$.

Daggy, B.P., O'Connell, N.C., Jerdack, G.R., Stinson, B.A., Setchell, K.D.R. (1997). Additive hypocholesterolemic effect of psyllium and cholestyraminein the hamster: influence on fecal sterol and bile acid profiles. J. Lipid Res. 38, 491-502.

De Almeida Costa, G. E., da Silva Queiroz-Monici, K., Reis, S. M. P. M., \& de Oliveira, A. C. (2006). Chemical composition, dietary fibre and resistant starch contents of raw and cooked pea, common bean, chickpea and lentil legumes. Food Chemistry, 94, 327-330.

El-Adawy, T. (2002). Nutritional composition and antinutritional factors of chickpeas (Cicer arietinum L.) undergoing different cooking methods and germination. Plant Foods for Human Nutrition, 57, 83-97.

Fantini, N., Cabras, C., Lobina, C., Colombo, G., Gessa, G., \& Riva, A. (2009). Reducing effect of a Phaseolus vulgaris dry extract on food intake, body weight, and glycemia in rats. Journal of Agricultural and Food Chemistry, 57(19), 9316-9323.

Gatchalian-Yee, M., Arimura, Y., Ochiai, E., Yamada, K., \& Sugano, M. (1997). Soybean protein lowers serum cholesterol levels in hamsters: Effect of debittered undigested fraction. Nutrition., 13, 633-639.

German, J. B., Xu, R., Walzem, R., Kinsella, J. E., Knuckles, B., Nakamura, M., \& Yokoyama, W. H. (1996). Effect of dietary fats and barley fiber on total cholesterol and lipoprotein cholesterol distribution in plasma of hamsters. Nutrition Research, 16, 1239-1246.

Hagio, M., Matsumoto, M., Fukushima, M., Hara, H., \& Ishizuka, S. (2009). Improved analysis of bile acids in tissuesand intestinal contents of rats using LC/ESI-MS. Journal of Lipid Research, 50, 173-180.

Han, K., Fukushima, M., Shimizu, K., Kojima, M., Ohba, K., \& Tanaka, A. (2003). Resistant starches of beans reduce the serum cholesterol concentration in rats. Journal of Nutritional Science and Vitaminology, 49, 281-286.

Han, K., lijuka, M., Shimada, K.-I., Sekikawa, M., Kuramochi, K., \& Ohba, K. (2005). Adzuki resistant starch lowered serum cholesterol and hepatic 3-hydroxy-3methylglutaryl-CoA mRNA levels and increased hepatic LDL-receptor and cholesterol 7a-hydroxylase mRNA levels in rats fed a cholesterol diet. British Journal of Nutrition, 94, 902-908.

Han, K., Sekikawa, M., Shimada, K.-I., Sasaki, K., Ohba, K., \& Fukushima, M. (2004). Resitant starch fraction prepared from kintoki bean affects gene expression of genes associated with cholesterol metabolism in rats. Experimental Biology and Medicine, 229, 787-792.

Hong, Y.-J., Turowski, M., Lin, J.-T., \& Yokoyama, W. H. (2007). Simultaneous characterization of bile acid, sterols, and determination of acyloglycerides in feces from soluble cellulose-fed hamsters using HPLC with evaporative lightscattering detection and APCI-MS. Journal of Agricultural and Food Chemistry, 55, 9750-9757. 
Hughes, J. S., Acevedo, E., Bressani, R., \& Swanson, B. G. (1996). Effects of dietary fiber and tannins on protein utilization in dry beans (Phaseolus vulgaris). Food Research International, 29(3-4), 331-338.

Juliano, B. O. (1999). Comparative nutritive value of various staple foods. Food Reviews International, 15, 399-434.

Kim, H., Bartley, G. E., Arvik, T., Lipson, R., Nah, S.-Y., Seo, K., \& Yokoyama, W. (2014). Dietary supplementation of chardonnay grape seed flour reduces plasma cholesterol concentration, hepatic steatosis, and abdominal fat content in high-fat diet-induced obese hamsters. Journal of Agricultural and Food Chemistry, 62(8), 1919-1925

Marzo, F., Alonso, R., Urdaneta, E., Arricibita, F. J., \& Ibanez, F. (2002). Nutritional quality of extruded kidney bean (Phaseolus vulgaris L. var. Pinto) and its effect on growth and skeletal muscle nitrogen fractions in rats. Journal of Animal Science, 80, 875-879.

McCrory, M. A., Hamaker, B. R., Lovejoy, J. C., \& Eichelsdoerfer, P. E. (2010). Pulse consumption, satiety, and weight management. Advances in Nutrition: An International Review Journal, 1, 17e30.

Mojica, L., Meyer, A., Berhow, M. A., \& de Mejia, E. G. (2015). Bean cultivars (Phaseolus vulgaris L.) have similar high antioxidant capacity, in vitro inhibition of a-amylase and a-glucosidase while diverse phenolic composition and concentration. Food Research International, 69, 38-48.

Morales, P., De Berrios, J., Varela, A. J., Burbano, C., Cuadrado, C., Muzquiz, M., \& Pedrosa, M. M. (2015). Novel fiber-rich lentil flours as snack-type functional foods: An extrusion cooking effect on bioactive compounds. Food \& Function, 6(9), 3135-3143.

Nakatani, A., Li, X., Miyamoto, J., Igarashi, M., Watanabe, H. A., Watanabe, K., et al. (2018). Dietary mung bean protein reduces high-fat diet-induced weight gain by modulating host bile acid metabolism in a gut microbiotadependent manner. Biochemical and Biophysical Research Communications, 501, 955e961.

Nergiz, C., \& Gokgoz, E. (2007). Effects of traditional cooking methods on some antinutrients and in vitro protein digestibility of dry bean varieties (Phaseolus vulgaris L.) grown in Turkey. International Journal of Food Science \& Technology, 42, 868-873.

Ngoh, Y.-Y., Choi, S. B., \& Gan, C.-Y. (2017). The potential roles of pinto bean (Phaseolus vulgariscv. Pinto) bioactive peptides in regulating physiological functions: Protease activating, lipase inhibiting and bile acid binding activities. Journal of Functional Foods, 33, 67-75.

Nilsson, A., Johansson, E., Ekström, L., \& Björck, I. (2013). Effects of a brown beans evening beal on metabolic risk markers and appetite regulating hormones at a subsequent standardized breakfast: A randomized cross-over study. PLoS One, 8(4), e59985.

Nosworthy, M. G., Medina, G., Franczyk, A. J., Neufeld, J., Appah, P., Utioh, A., ... House, J. D. (2018). Effect of processing on the in vitro and in vivo protein quality of beans (Phaseolus vulgaris and Vicia Faba). Nutrients, 10(6), 671.

Perez-Hidalgo, M., Guerra-Hernandez, E., \& Garcia-Villanova, B. (1997). Determination of insoluble dietary fiber compounds: Cellulose, hemicellulose and lignin in legumes. Ars Pharmaceutica., 38, 357-364.

Petersen, K. S., Flock, M. R., Richter, C. K., Mukherjea, R., Slavin, J. L., \& Kris-Etherton, P. M. (2017). Healthy dietary patterns for preventing cardiometabolicdisease: The role of plant-based foods and animal products. Current Developments in Nutrition, 1(12), 117.001289.

Reeves, P. G., Nielsen, F. H., \& Fahey, G. C. (1993). AlN-93 purified diets for laboratory rodents: final report of the American Institute of Nutrition ad hoc writing committee on the reformulation of the AIN-76A rodent diet. Nutrition, 123(11), 467-72.

Roman, J. A., \& Sgarbieri, V. C. (2005). Obtention and chemical and nutritional characterization of different bovine casein concentrates. Revista de Nutrição, 18(1), 75-83.

Rubio, L. A., Aranda-Olmedo, I., Contreras, S., Góngora, T., Domínguez, G., PeraltaSánchez, J. M., \& Martín-Pedrosa, M. (2020). Inclusion of limited amounts of extruded legumes plus cereal mixes in normocaloric or obesogenic diets for rats: Effects on intestinal microbiota composition. Journal of the Science of Food and Agriculture. 9(6), 704. https://doi.org/10.3390/foods9060704.

Sandberg, A. (2002). Bioavailability of minerals in legumes. The British Journal of Nutrition, 88(S3), S281-S285.

Shimelis, E. A., \& Rakshit, S. K. (2007). Effect of processing on antinutrients and in vitro digestibility of kidney bean (Phaseolus vulgaris L.) varieties grown in East Africa. Food Chemistry, 103, 161-172.

Siddiq, M., \& Uebersax, M. A. (2012). Dry beans and pulses production and consumption-An overview. In M. Siddiq, \& M. A. Uebersax (Eds.), Dry beans and pulses production, processing and nutrition, (pp. 1-22). Oxford: Blackwell Publishing Ltd.

Song, H., Han, W., Yan, F., Xu, D., Chu, Q., \& Zheng, X. (2016). Dietary Phaseolus vulgaris extract alleviated diet-induced obesity, insulin resistance and hepatic steatosis and alters gut microbiota composition in mice. Journal of Functional Foods, 20, 236-244. https://doi.org/10.1016/j.jf.2015.10.022.

Spadafranca, A., Rinelli, S., Riva, A., Morazzoni, P., Magni, P., \& Bertoli, S. (2013). Phaseolus vulgaris extract affects glycometabolic and appetite control in healthy human subjects. British Journal of Nutrition, 109, 1789-1795.

Srisuma, N., Ruengsakulrach, S., Uebersax, M. A., Bennink, M. R., \& Hammerschmidt, R. (1991). Cell wall polysaccharides of navy beans (Phaseolus vulgaris). Journal of Agricultural and Food Chemistry, 39, 855-858.

Tharanathan, R. N., \& Mahadevamma, S. (2003). Grain legumes-a boon to human nutrition. Trends in Food Science \& Technology, 14, 507-518.

U.S. Department of Health and Human Services. Dietary Guidelines for Americans. 2005. Published online at www.health.gov/DietaryGuidelines/dga2005/ document/default.htm. Washington, DC, U.S.A. 2019.

Wahlström, A., Sayin, S., Marschall, H. U., \& Backhed, F. (2016). Intestinal crosstalk between bile acids and microbiota and its impact on host metabolism. Cell Metabolism, 24, 41e50.

Wang, N., Hatcher, D. W., Tyler, R. T., Toews, R., \& Gawalko, E. J. (2010). Effect of cooking on the composition of beans (Phaseolus vulgaris L.) and chickpeas (Cicer arietinum L.). Food Research International, 43, 589-594.

Xu, B. J., \& Chang, S. K. C. (2008). Total phenolic content and antioxidant properties of eclipse black beans (Phaseolus vulgaris L.) as affected by processing methods. Journal of Food Science, 73, H19-H27.

\section{Publisher's Note}

Springer Nature remains neutral with regard to jurisdictional claims in published maps and institutional affiliations.

Ready to submit your research? Choose BMC and benefit from:

- fast, convenient online submission

- thorough peer review by experienced researchers in your field

- rapid publication on acceptance

- support for research data, including large and complex data types

- gold Open Access which fosters wider collaboration and increased citations

- maximum visibility for your research: over $100 \mathrm{M}$ website views per year

At $\mathrm{BMC}$, research is always in progress.

Learn more biomedcentral.com/submissions 